\title{
AGTRAP wt Allele
}

National Cancer Institute

\section{Source}

National Cancer Institute. AGTRAP wt Allele. NCI Thesaurus. Code C101501.

Human AGT RAP wild-type allele is located in the vicinity of 1 p36.22 and is approximately

$19 \mathrm{~kb}$ in length. This allele, which encodes type-1 angiotensin II receptor-associated

protein, is involved in the modulation of angiotensin signaling. 